\title{
HUBUNGAN ANTARA MODAL INTELEKTUAL DENGAN NILAI PASAR DAN KINERJA KEUANGAN DI PERUSAHAAN PUBLIK INDONESIA
}

\section{THE RELATIONSHIP BETWEEN INTELLECTUAL CAPITAL, MARKET VALUE AND FINANCIAL PERFORMANCE IN INDONESIAN PUBLIC COMPANIES}

\author{
Akbar Yusuf $f^{2}$, Darwis Said ${ }^{2}$, Mediaty $^{2}$ \\ ${ }^{I}$ Jurusan Akuntansi, Fakultas Ekonomi, Universitas Muhammadiyah Kupang, \\ ${ }^{2}$ Jurusan Akuntansi, Fakultas Ekonomi, Universitas Hasanuddin
}

\begin{abstract}
Alamat korespondensi:
Fakultas Ekonomi

Universitas Muhammadiyah Kupang

Jl. KH. Ahmad Dahlan, No. 17, Kupang-NTT

HP. 081339394825

Email : akbaryusuf10@yahoo.co.id
\end{abstract}




\begin{abstract}
Abstrak
Modal intelektual sebagai sumber daya perusahaan telah diakui menjadi pendorong nilai dan keunggulan komparatif perusahaan. Penelitian ini bertujuan menguji efek utama dan efek moderasi hubungan modal intelektual melalui modal manusia, modal struktural, dan modal fisik dan keuangan dengan nilai pasar dan kinerja keuangan. Penelitian dilakukan di Bursa Efek Indonesia dengan menggunakan data sekunder untuk menguji hipotesis dengan metode pooled least square. Pengambilan sampel dilakukan secara purposive sampling menghasilkan 63 observasi tahun 2009-2011. Variabel utama dalam penelitian ini adalah nilai pasar dan kinerja keuangan sebagai variabel dependen, dan modal manusia, modal struktural, modal fisik, dan interaksi modal manusia dengan modal struktural sebagai variabel independen, yang dikontrol oleh ukuran perusahaan dan leverage. Analisis karakteristik data menggunakan deskriptif statistik dan pengujian setiap hipotesis dilakukan dengan model regresi linier berganda. Hasil studi membuktikan bahwa, modal manusia hanya berpengaruh positif terhadap kinerja keuangan, sementara hubungannya dengan nilai pasar adalah gagal. Modal struktural berpengaruh positif terhadap nilai pasar, namun gagal dalam hubungannya dengan kinerja keuangan. Modal fisik terbukti berpengaruh positif terhadap nilai pasar dan kinerja keuangan. Modal stuktural dijadikan sebagai moderasi ternyata gagal memoderasi hubungan modal manusia dengan nilai pasar. Di sisi lain, modal struktural dapat menjadi variabel moderasi secara negatif hubungan modal manusia dengan kinerja keuangan. Sehingga disimpulkan bahwa secara umum para investor dan perusahaan memberikan penilaian yang lebih terhadap modal fisik dan keuangan dari pada modal manusia dan modal struktural, yang dapat berakibat lemahnya daya saing perusahaan secara berkelanjutan.
\end{abstract}

Kata kunci : modal manusia, modal struktural, modal fisik dan keuangan, nilai tambah, moderasi

\begin{abstract}
Intellectual capital as a resource company has acknowledged being a value driver and comparative advantages of the company. This research aims to test the main effect and moderating effect relations intellectual capital represented by human capital, structural capital and physical capital with market value and financial performance. Research conducted at the Indonesia Stock Exchange with secondary data are used to test the hypothesis with pooled least square method. Sampling done in a purposive sampling resulted in 63 years observation 2009-2011. Main variables in this research is market value and financial performance as the dependent variables, and human capital, structural capital, capital employed, interaction human capital with structural capital as the independent variable, controlled by Size and Leverage of the company. Characteristic data analysis using descriptive statistics and testing any hypothesis done with multiple linear regression model. The study proves that human capital is only a positive effect on financial performance, while the relationship with the market value is failing. Structural capital positive effect on market value, but failed in relation to financial performance. Capital employed proven positive effect on market value and financial performance. Structural capital serve as moderating variables failed to moderate the relationship human capital with the market value, on the other hand, structural capital proved to be a moderating variable in a negative the relationship human capital with financial performance. So it is concluded that in general investors and companies provide better assessment of the physical capital than human capital and structural capital, which may result in lack of competitiveness in a sustainable enterprise.
\end{abstract}

Keywords: human capital, structural capital, capital employed, value added, moderating 


\section{PENDAHULUAN}

Modal intelektual sebagai bagian sumber daya perusahaan telah diakui sebagai pendorong nilai dan keunggulan komparatif perusahaan. Pandangan teori berbasis sumber daya (resource-based theory-RBT) perusahaan menyatakan bahwa perusahaan mencapai keunggulan komparatif yang berkelanjutan dan memperoleh keuntungan yang lebih besar dengan memiliki atau mengontrol aset-aset strategis baik tangible assets (aset berwujud) maupun intangible assets (aset tidak berwujud) (Wernerfelt, 1984), sementara pandangan stakeholder theory merekomendasikan bahwa ukuran terbaik kinerja keuangan dari laba akuntansi (profit accounting) adalah menciptakan total kekayaan (the total wealth created) atau nilai tambah bersih (net value added) (Riahi-Belkaoui, 2003). Intangible dan tangible assets merupakan sumber daya utama perusahaan dalam mencapai keunggulan komparatif yang berkelanjutan dan keuntungan yang lebih besar melalui penciptaan nilai (value creation). Bahkan Arvidsson (2011) dengan munculnya era knowledge-based dan innovationdriven, perusahaan saat ini semakin bergantung pada intangible assets, yang juga disebut sebagai intangibles atau intellectual capital (IC) dalam proses value-creation.

Stewart (1997); dan Kannan et al. (2004) mendefinisikan IC sebagai material intelektual (pengetahuan, informasi, kekayaan intelektual dan pengalaman) yang dapat dimanfaatkan untuk menciptakan kekayaan. Lebih spesifik oleh Edvinsson et al. (1997) dalam Chen et al. (2005) mendefinisikan IC sebagai perbedaan antara nilai pasar perusahaan dan nilai buku. Riahi-Belkaoui (2003) IC sebagai pengetahuan khusus dan berharga yang dimiliki organisasi dengan kualifikasi sebagai aset strategis yang terletak pada hubungan potensial antara IC di satu sisi dan kinerja perusahaan di sisi lain. Sehingga selayaknya perusahaan menjadikan IC sebagai pendorong utama value creation untuk dapat meningkatkan financial performance dan market value perusahaan. Namun pengukuran yang tepat terhadap IC adalah masalah kompleks yang sulit terutama dalam mengonsep, mendefinisikan dan mengukurnya (Aho et al., 2011). Pulic (2004) tidak mengukur secara langsung IC perusahaan, tetapi mengajukan suatu ukuran untuk menilai efisiensi dari nilai tambah (value added) sebagai hasil dari kemampuan intelektual perusahaan yang disebut Value Added Intellectual Coefficient (VAICTM). IC memiliki dua komponen utama, yakni human capital (HC) dan structural capital (SC), dan semua pengeluaran kepada karyawan termasuk dalam HC. Lebih lanjut Pulic (2004) karena HC tidak dapat menciptakan nilai sendiri, maka diperlukan juga informasi tentang capital employed (CE). Yang baru dalam konsep ini menurut Pulic (2004) adalah gaji tidak lagi menjadi bagian dari INPUT, yang berarti semua biaya yang terkait dengan karyawan tidak diperlakukan sebagai biaya tetapi 
merupakan investasi. Sehingga Pulic (2004) komponen utama dari VAICTM dapat dilihat dari human capital efficiency coefficient-HCE, structure capital efficiency coefficient-SCE, dan capital employed efficiency coefficient-CEE).

Firer et al. (2003) di Afrika Selatan, menunjukkan bahwa secara umum hanya CEE memiliki efek positif terhadap kinerja perusahaan, sementara dua komponen utama IC yakni HC dan SC gagal memberikan efek. Chen et al. (2005) di Taiwan, menemukan bahwa IC memiliki efek positif pada nilai pasar dan kinerja keuangan. Zéghal et al. (2010) di Inggris, membuktikan bahwa IC berdampak positif pada kinerja ekonomi dan keuangan, namun hubungan antara IC dan kinerja pasar hanya signifikan bagi industri teknologi tinggi. Studi terkini dilakukan oleh Mehralian et al. (2012) di Iran, menunjukkan bahwa IC dapat menjelaskan profitabilitas tetapi tidak terhadap produktivitas dan nilai pasar. Penelitian di Indonesia, diantaranya Ulum et al. (2008), menunjukkan bahwa adanya pengaruh positif IC $\left(\mathrm{VAIC}^{\mathrm{TM}}\right.$ ) terhadap kinerja keuangan perusahaan. Solikhah et al. (2010) menemukan bahwa IC berpengaruh positif terhadap kinerja keuangan dan pertumbuhan perusahaan, namun tidak berpengaruh terhadap nilai pasar. Sementara Yuniasih et al. (2010), menemukan bahwa IC tidak berpengaruh pada kinerja pasar. Demikian pula, hasil investigasi Widarjo (2011) menunjukkan bahwa IC yang diukur dengan $\mathrm{VAIC}^{\mathrm{TM}}$ tidak berpengaruh secara signifikan terhadap nilai perusahaan.

Berbagai hasil penelitian baik dalam konteks Indonesia maupun internasional menunjukkan hasil yang inkonsisten, terutama tentang IC dengan kinerja perusahaan maupun nilai perusahaan, sehingga menarik untuk dikaji kembali, maka diajukan hipotesis penelitian ini adalah: H1a: HCE secara positif berhubungan dengan market value, H1b: HCE secara positif berhubungan dengan return on assets, H2a: SCE secara positif berhubungan dengan market value, H2b: SCE secara positif berhubungan dengan return on assets, H3a: CEE secara positif berhubungan dengan market value, H3b: CEE secara positif berhubungan dengan return on assets, H4a: efisiensi dalam menggunakan structural capital berdampak positif terhadap hubungan HCE dengan market value, H4b: efisiensi dalam menggunakan structural capital berdampak positif terhadap hubungan HCE dengan return on assets.

Dengan demikian, maka tujuan penelitian ini adalah untuk memperoleh bukti empiris tentang konsekuensi hubungan direct dan moderasi IC (VAIC ${ }^{\mathrm{TM}}$ ) melalui komponenkomponennya terhadap kinerja keuangan (financial performance) dan nilai pasar (market value) perusahaan. Penelitian ini juga menggunakan dua faktor kontrol yakni Leverage dan Size perusahaan. Di samping itu, model pengukuran IC yang digunakan dalam penelitian ini adalah model VAIC ${ }^{\mathrm{TM}}$ (Pulic, 2004). 


\section{BAHAN DAN METODE}

\section{Lokasi dan desain penelitian}

Penelitian ini dilakukan di Bursa Efek Indonesia (BEI). Jenis penelitian yang digunakan adalah pengujian hipotesis (hypothesis testing) dengan melakukan pengujian hubungan terhadap semua variabel yang diteliti (causal research). Penelitian ini merupakan studi empiris menggunakan data panel (pooling data) dengan pendekatan pooled least square (PLS), yakni mengasumsikan bahwa intersep dan koefisien yang sama untuk semua perusahaan selama tiga tahun $(2009,2010$, dan 2011).

\section{Variabel dan pengukurannya}

Variabel dependen penelitian ini adalah market value dan financial performance. Market value diproksikan dengan market-to-book value ratio of equity (M/B), sementara financial performance diproksikan dengan Return on assets (ROA). M/B sebagai rasio total kapitalisasi pasar (harga saham kali jumlah saham biasa yang beredar) dengan nilai buku aktiva bersih, sebagai proksi untuk nilai pasar saham (Zéghal et al., 2010; Firrer et al., 2003; Chang, 2009a; Chu et al., 2011), dan ROA sebagai rasio dari laba sebelum beban bunga dan pajak (laba operasi) dengan nilai buku total aset (Firrer et al., 2003; Chen et al., 2005; Zéghal et. al., 2010; Chan, 2009a; Chu et al., 2011). Variabel independen dalam studi ini adalah human capital efficiency (HCE), structural capital efficiency (SCE), dan capital employed efficiency (CEE) sebagai proksi intellectual capital (IC) yang diukur dengan menggunakan model Value Added Intellectual Coefficient $\left(\mathrm{VAIC}^{\mathrm{TM}}\right.$ ) yang dikembangkan oleh Pulic (2004). Langkah-langkah perhitungan $\mathrm{VAIC}^{\mathrm{TM}}$ adalah (Pulic, 2004): VA = OUT $\mathrm{IN}, \mathrm{HCE}=\mathrm{VA} / \mathrm{HC}, \mathrm{SC}=\mathrm{VA}-\mathrm{HC}, \mathrm{SCE}=\mathrm{SC} / \mathrm{VA}, \mathrm{ICE}=\mathrm{HCE}+\mathrm{SCE}, \mathrm{CEE}=\mathrm{VA} / \mathrm{CE}$, $\mathrm{VAIC}=\mathrm{ICE}+\mathrm{CEE}$, dimana VA adalah value added, OUT adalah total penjualan dan pendapatan lain, IN sebagai beban penjualan dan biaya-biaya lain (selain biaya terkait karyawan), HC yaitu biaya gaji/upah dan biaya terkait karyawan lainnya (gaji dan upah, biaya pelatihan dan pengembangan karyawan, dan professional fee), HCE adalah human capital efficiency coefficient; SC adalah structural capital, SCE adalah structural capital efficiency coefficient, ICE adalah intellectual capital efficiency coefficient, CE adalah book value of the net assets, CEE adalah capital employed efficiency coefficient, dan VAIC yaitu value added intellectual coefficient.

Variabel moderasi peneilitian ini adalah SCE yang diuji menggunakan model "nilai selisih mutlak" yang diajukan oleh Frucot dan Shearon pada tahun 1991 dalam Ghozali (2011), sementara variabel kontrol yang digunakan adalah Size dan Leverage. Size diukur dengan log natural dari market capitalisation (Riahi-Belkaoui, 2003; Firer et al., 2003; Chan, 2009a; Calisir et al., 2010; Chu et al., 2011), dan Leverage (DEBT) diukur dengan total debt 
terhadap nilai buku total assets. (Riahi-Belkaoui, 2003; Chan, 2009a; Calisir et al., 2010; Chu et al., 2011).

\section{Populasi dan sampel}

Populasi penelitian ini adalah seluruh perusahaan non sektor pertambangan yang listed dan go public di Bursa Efek Indonesia (BEI) selama tahun 2009, 2010, dan 2011. Pemilihan sampel secara purposive sampling dengan kriteria: a) perusahaan dengan negatif nilai buku stockholders' equity, atau perusahaan dengan nilai negatif $\mathrm{HC}$ atau SC dikeluarkan dari sampel (Firrer et al., 2003; Chen et al., 2005; dan Zéghal et al., 2010), b) perusahaan yang hilang beberapa data juga dikecualikan (Chen et al., 2005; Zéghal et al., 2010); c) perusahaan yang intens melakukan R\&D (Chen et al., 2005; dan Zéghal et al., 2010).

\section{Pengumpulan data}

Metode pengumpulan data yang digunakan adalah metode tidak langsung berupa data arsip atau data sekunder yang diperoleh dari laporan keuangan tahunan perusahaan yang terdaftar di BEI dan tersedia di (http://www.idx.co.id/) dan Indonesian capital market directory (ICMD) tahun 2009- 2011.

\section{Analisis data}

Analisis data menggunakan deskriptif statistik untuk menganalisis karakteristik data, dan pengujian hubungan langsung dan moderasi antara modal intelektual dengan market value dan financial performance menggunakan model regresi linier berganda, yang diolah menggunakan SPSS for windows 17.

\section{HASIL PENELITIAN}

\section{Deskriptif objek penelitian}

Tabel 1 menunjukkan bahwa jumlah perusahaan secara keseluruhan non sektor pertambangan yang tercatat di BEI hingga tahun 2011 sebanyak 359 perusahaan sebagai populasi dalam penelitian ini, kemudian dilakukan pemilihan sampel menggunakan metode purposive sampling, maka terpilih perusahaan yang memiliki data berturut-turut selama tiga tahun sebanyak 21 perusahaan sampel kali tiga tahun sama dengan 63 observasi/sampel.

\section{Deskriptif statistik}

Deskriptif statistik pada Tabel 2 menunjukkan nilai mean M/B sebesar 3.99, yang berarti bahwa secara umum para investor menilai perusahaan sampel di atas nilai buku net assets seperti yang dilaporkan dalam financial statements. Konsekuensinya, sekitar $60 \%$ market value perusahaan sampel tidak terefleksi di dalam financial statements. Sementara nilai mean pada ICE sebesar 3.08 menunjukkan bahwa human capital dan structural capital 
menciptakan rata-rata VA sebesar Rp. 3.08,- dari setiap Rp. 1,- net asset, sementara capital employed hanya menciptakan VA sebesar Rp. 0.43,- dari setiap Rp. 1,- net asset. Secara parsial dapat dilihat kontribusi dari ketiga komponen $\mathrm{VAIC}^{\mathrm{TM}}$, ternyata $\mathrm{HC}$ memberikan niai mean yang lebih tinggi.

\section{Hasil Analisis Regresi Berganda}

Sebelum dilakukan analisis regresi berganda untuk menguji setiap hipotesis, dilakukan uji asumsi klasik terhadap model-model empiris agar memperoleh model unbiased estimator. Hasil pengujian awal menunjukkan beberapa model belum terpenuhi asumsi klasik baik uji normalitas, multikolinieritas, maupun heteroskedastisitas, sehingga dilakukan transformasi data dalam bentuk logaritma natural (Gujarati et al., 2010) sampai model-model yang digunakan terpenuhi semua asumsi klasik. Hasil transformasi tampak pada Tabel 3 yang kemudian digunakan untuk menguji setiap hipotesis terkait. Pada Tabel 3 terlihat bahwa pengujian asumsi klasik atas model-model pada kolom (2), menunjukkan pelanggaran asumsi, sehingga dilakukan transformasi data dalam bentuk logaritma natural (Ln), maka terjadi transformasi model yang terlihat pada kolom (3). Dengan demikian maka model-model pada kolom (3) yang digunakan untuk pengujian setiap hipotesis dalam penelitian ini.

Hasil analisis regresi berganda pada Tabel 4. Panel A menunjukkan bahwa nilai koefisien HCE sebesar -0.02 adalah tidak signifikan pada level $\alpha=5 \%$, sehingga hipotesis H1a bahwa HCE secara positif berhubungan dengan M/B ditolak. Sedangkan dua komponen VAIC $^{\mathrm{TM}}$ lainnya, yaitu SCE dan CEE nilai koefisien masing-masing 1.17 dan 1.38 adalah signifikan pada level $\alpha=10 \%$ dan $1 \%$, sehingga hipotesis H2a dan H3a bahwa SCE dan CEE secara positif berhubungan dengan M/B dapat diterima. Panel B, nilai koefisien HCE dan CEE masing-masing sebesar 0.17 dan 0.13 adalah signifikan pada level $\alpha=1 \%$, sehingga hipotesis H1b dan H3b bahwa HCE dan CEE secara positif berhubungan dengan ROA dapat diterima. Sedangkan nilai koefisien SCE sebesar -0.02 adalah tidak signifikan, sehingga hipotesis H2b bahwa SCE secara positif berhubungan dengan ROA ditolak. Hubungan HCE dengan M/B dan ROA yang dimoderasi oleh SCE juga dilihat pada Tabel 4. Panel C, variabel moderating AbsHCE_SCE ternyata tidak signifikan dengan signifikansi 0.450 di atas 0.05 , sehingga hipotesis H4a bahwa efisiensi dalam menggunakan SC berdampak positif terhadap hubungan HCE dengan M/B ditolak. Panel D, nilai koefisien variabel moderating AbsHCE_SCE sebesar -0.096 signifikan dengan nilai 0.027 di bawah 0.05 , sehingga walaupun SCE merupakan variabel moderating, namun bersifat negative interaction hubungan antara HCE dengan ROA, maka hipotesis $\mathrm{H} 4 \mathrm{~b}$ bahwa efisiensi dalam menggunakan SC berdampak positif terhadap hubungan HCE dengan ROA ditolak. 


\section{PEMBAHASAN}

Penelitian ini memperlihatkan bahwa modal manusia hanya berpengaruh positif terhadap financial performance, sementara hubungannya dengan market value adalah gagal. Modal struktural berpengaruh positif terhadap market value, namun gagal dalam hubungannya dengan financial performance. Modal fisik terbukti berpengaruh positif terhadap market value dan financial performance. Hubungan modal manusia dengan market value dan financial performance yang dimoderasi oleh modal stuktural semuanya tidak berpengaruh positif. Modal struktural dapat menjadi variabel moderasi secara negatif hubungan modal manusia dengan financial performance, namun menjadi gagal dalam memoderasi hubungan modal manusia dengan market value.

Human capital (HC) merupakan unsur yang sangat penting dari konstruk IC (Bontis, 1998, 1999, 2001a, b, 2002a, b). Stewart (1997); dan Kannan et al. (2004) intellectual capital merupakan material intelektual (pengetahuan, informasi, kekayaan intelektual dan pengalaman) yang dapat dimanfaatkan untuk menciptakan kekayaan. Sehingga IC memiliki kemampuan untuk meningkatkan profitabilitas perusahaan, yang memungkinkan perusahaan untuk menciptakan produk dan layanan baru, proses bisnis baru, dan bentuk organisasi baru (Sullivan Jr. et al., 2000). Namun, dalam penelitian ini memberikan hasil yang kontradiksi bahwa HC tidak dapat menjadi penentu market value. Temuan riset ini sama dengan di Hong Kong (Chu et al., 2011), di Afrika Selatan (Firer et al., 2003), dan di Iran (Mehralian et al,. 2012). Hasil riset mengindikasikan bahwa investor kurang mempertimbangkan aspek sumber daya manusia yang diakui sebagai sumber keunggulan komparatif perusahaan, ketika mengambil keputusan investasinya di perusahaan sampel.

Konstruk IC yang lain adalah structural capital meliputi seluruh non-human storehouses of knowledge dalam organisasi, yang meliputi database, organisational charts, process manuals, strategies, routines dan segala hal yang membuat nilai perusahaan lebih besar daripada nilai materialnya (Bontis et al., 2000). Pandangan tersebut ditemukan dalam penelitian ini, yang menunjukkan bahwa SCE turut menentukan nilai pasar (M/B). Hasil riset di Taiwan juga ditemukan bahwa SCE turut menentukan nilai pasar (Chen et al. 2005). Hal yang sama juga ditemukan di Hong Kong (Chu et al., 2011), dan di Italia (Veltri et al., 2011). Hasil riset ini menunjukkan bahwa para investor menempatkan nilai lebih kepada SC dalam keputusan investasinya, karena dinilai SC sebagai tempat transformasi kompotensi HC untuk menghasilkan produk-produk inovatif.

Sumber daya yang terungkap dalam financial statement adalah capital employed (CE) atau modal fisik dan keuangan yang menjadi pusat perhatian pasar. Hal ini dibuktikan dalam 
penelitian ini bahwa pasar memberikan penilaian yang lebih terhadap CE yang ditunjukkan dengan nilai koefisien 1.383 yang lebih tinggi dibandingkan dengan modal manusia dan modal struktural. Di Taiwan juga ditemukan bahwa pasar bereaksi positif terhadap CE (Chen et al. 2005). Begitu pula di Hong Kong (Chu et al., 2011), dan di Italia (Veltri et al., 2011).

Hasil riset ini membuktikan bahwa, dari ketiga komponen intellectual capital, ternyata para investor memberikan penilaian yang lebih tinggi terhadap modal fisik dan keuangan (CEE) atau tangible assets dari pada modal manusia (HC) dan modal struktural (SC) atau intangible assets. Kondisi ini kontradiksi dengan pandangan Arvidsson (2011), bahwa dengan munculnya era knowledge-based dan innovation-driven, perusahaan semakin bergantung pada intangible assets dalam proses value-creation. Kondisi ini menunjukkan bahwa perusahaanperusahaan yang disurvei beroperasi dalam pasar "old economies", seperti dinyatakan Bose et al. (2007) perusahaan yang beroperasi dalam era "old economies", market value terutama berada dalam tangible asset, sedangkan dalam "new economies" nilai diciptakan dan dimiliki (created and held) terutama dari penerapan pengetahuan (knowledge) dan IC perusahaan.

Investasi dalam sumber daya manusia mempunyai pengaruh yang besar terhadap peningkatan produktivitas, yang dapat didorong melalui pendidikan dan pelatihan (Becker, 1964). Produktifitas yang tinggi akan diikuti dengan peningkatan laba operasi sebagai wujud penggunaan total aset yang diinvestasikan dalam sumber daya manusia. Hasil riset ini pun memberikan hasil yang mendukung Becker (1964) yakni HC sebagai salah satu penentu ROA yang merupakan rasio laba operasi terhadap nilai buku total aset. Hasil temuan ini sama dengan temuan Chen et al. (2005) di Taiwan, Ulum et al. (2008) di Indonesia, dan Chu et al. (2011) di Hong Kong.

Pandangan resources-based menyatakan bahwa perusahaan mendapatkan keunggulan kompetitif dan kinerja yang unggul melalui memiliki, menguasai dan menggunakan aset-aset strategis (Wernerfelt, 1984), sementara riset ini memberikan hasil yang kontradiksi bahwa SC tidak termasuk sebagai penentu ROA, seperti temuan Chan (2009b), Mehralian et al. (2012), dan Ulum et al. (2008). Stewart (1997) memberikan analogi tentang structural capital, bahwa HC bagaikan getah yang mengalir di bawah kulit batang pohon, menghasilkan inovasi dan pertumbuhan, kemudian lingkaran pertumbuhan tersebut akan menjadi kayu, sebagai bagian struktur pohon. Lebih lanjut Stewart (1997), yang harus dilakukan para pemimpin adalah menyimpan dan mempertahankan pengetahuan sehingga pengetahuan tersebut menjadi properti perusahaan, yang disebut sebagai structural capital.

Modal fisik dan keuangan (CE) sebagai basis pengukuran akuntansi tradisional memiliki peran yang sangat signifikan dalam menciptakan kinerja perusahaan. Hasil studi 
menunjukkan bahwa CE memiliki kontribusi yang sangat signifikan dalam menentukan nilai ROA. Hasil studi ini mendukung Chen et al. (2005), Mehralian et al. (2012), Zéghal et al. (2010), Chan (2009b), Chu et al. (2011), yang mengindikasikan bahwa, manajemen dan investor memberikan penilaian yang lebih terhadap modal fisik dalam menciptakan laba bersih, jika dibandingkan dengan investasi pada HC yang merupakan unsur utama IC, sehingga proporsi total aset yang tertanam dalam HC sangatlah kurang.

Veltri et al. (2011) mengutip pandangan para ahli bahwa meskipun HC dipandang sebagai unsur utama IC dan sumber daya terpenting keunggulan kompetitif yang berkelanjutan, tapi tidak memiliki efek utama secara signifikan terhadap kinerja perusahaan, tetapi lebih merupakan suatu hubungan tidak langsung. Pandangan Veltri et al. (2011) ini searah dengan contingency theory, bahwa desain berbagai komponen sistem akuntansi tergantung pada kontinjensi tertentu yang dapat menciptakan sebuah hubungan yang sempurna (Riahi-Belkaoui, 1989). Lebih jauh Huang et al. (2010) komponen-komponen IC dapat dipahami sebagai karakteristik organisasi yang dipengaruhi oleh kontinjensi pada lingkungan operasional. Namun hasil yang kontradiksi ditemukan dalam riset ini, bahwa SC tidak berhasil menjadi variabel moderasi hubungan HC dengan market value. Gagalnya SC sebagai variabel moderasi dikarenakan investor tidak menempatkan penilaiannya terhadap modal struktural yang meliputi modal pelanggan dan modal organisasi sebagai aset strategis dalam mendukung modal manusia untuk menciptakan nilai pasar (M/B).

Nilai Adjusted $\mathrm{R}^{2}$ pada model $2 \mathrm{~b}$ Panel D sebesar 0.766 setelah dimasukkan variabel interaksi ternyata mengalami peningkatan dari nilai Adjusted $\mathrm{R}^{2}$ pada model 1b, panel B sebesar 0.754 tanpa interaksi. Hal ini berarti kehadiran variabel SCE sebagai moderasi hubungan antara HCE dengan ROA adalah bermakna. Temuan ini menunjukkan bahwa walaupun SCE merupakan variabel moderating namun bersifat negative interaction hubungan antara HCE dengan ROA. Kondisi ini mengindikasikan kurang berperannya HC dalam mentrasformasi pengetahuan dan pengalamannya ke dalam sistem dan proses prosedur, sehingga berdampak semakin kurangnya eksistensi SC dalam memampukan perusahaan untuk menciptakan laba operasi (ROA).

Dalam perspektif teori resources-based, perusahaan mendapatkan keunggulan kompetitif dan kinerja yang unggul melalui memiliki, menguasai dan menggunakan aset-aset strategis (Wernerfelt, 1984), untuk meningkatkan kinerja perusahaan (Riahi-Belkaoui, 2003), sehingga dapat disimpulkan structural capital seharusnya memoderasi hubungan human capital dengan market value dan financial performance, karena human capital sendiri tidak dapat beroperasi tanpa tersedianya structural capital yang memadai dalam menciptakan 
kemampuan daya saing dan keunggulan komparatif secara berkelanjutan di pasar global maupun di pasar regional Asia.

\section{KESIMPULAN DAN SARAN}

Kami menyimpulkan bahwa modal manusia hanya berpengaruh positif terhadap kinerja keuangan, sementara hubungannya dengan nilai pasar adalah gagal. Modal struktural berpengaruh positif terhadap nilai pasar, namun gagal dalam hubungannya dengan kinerja keuangan. Modal fisik terbukti berpengaruh positif terhadap nilai pasar dan kinerja keuangan. Modal stuktural dijadikan sebagai moderasi ternyata gagal memoderasi hubungan modal manusia dengan nilai pasar. Di sisi lain, modal struktural dapat menjadi variabel moderasi secara negatif hubungan modal manusia dengan kinerja keuangan. Secara umum para investor dan perusahaan memberikan penilaian yang lebih terhadap modal fisik dan keuangan dari pada modal manusia dan modal struktural, yang dapat berakibat lemahnya daya saing perusahaan secara berkelanjutan. Sehingga disarankan kepada para investor dan perusahaan agar menyeimbangkan penilaian dan penggunaan modal manusia, modal struktural dan modal fisik dalam menciptakan total kekayaan (value added) untuk meningkatkan keunggulan kompetitif dan komparatif perusahaan dan bangsa Indonesia di pasar global maupun regional Asia secara berkelanjutan. 


\section{DAFTAR PUSTAKA}

Aho S., Ståhle S. \& Ståhle P. (2011). A critical assessment of Stewart's CIV Method. Measuring Business Excellence. Vol. 15 No. 4 2011, pp. 27-35.

Arvidsson S. (2011). Disclosure of non-financial information in the annual report, A management-team perspective. Journal of Intellectual Capital. Vol. 12 No. 2, pp. 277300

Becker G. S. (1964). Human Capital: A Theoretical and Empirical Analysis with Special Reference to Education (3rd Edition). The University of Chicago Press.

Bontis N. (1998). Intellectual capital: an exploratory study that develops measures and models. Management Decision. 36/2 [1998] 63-76.

. (2004). National Intellectual Capital Index, A United Nations initiative for the Arab region. Journal of Intellectual Capital. Vol. 5 No. 1, pp. 13-39.

(2001b). Managing Organizational Knowledge By Diagnosing Intellectual Capital: Framing and Advancing the State of the Field. Managing Organizational Knowledge. Idea Group Publishing.

Bontis N., Keow W. C. C. \& Richardson S. (2000). Intellectual capital and business performance in Malaysian industries. Journal of Intellectual Capital. Vol. 1 No. 1, pp. 85-100.

Bontis N. (2001a). Assessing knowledge assets: a review of the models used to measure intellectual capital. International Journal of Management Reviews. Volume 3, Issue 1 pp. 41-60.

Bose S. \& Thomas K. (2007). Applying the balanced scorecard for better performance of intellectual capital. Journal of Intellectual Capital. Vol. 8 No. 4, pp. 653-665.

Cabrita M. Do Rosário, Bontis, N. (2008). Intellectual capital and business performance in the Portuguese banking industry. Int. J. Technology Management, Vol. 43, Nos. 1-3.

Calisir F., Gumussoy C. A., Bayraktaroğlu A. E. \& Deniz, E. (2010). Intellectual capital in the quoted Turkish ITC sector. Journal of Intellectual Capital. Vol. 11 No. 4, pp. 537553.

Chen M., Cheng S., \& Hwang Y. (2005). An empirical investigation of the relationship between intellectual capital and firms' market value and financial performance. Journal of Intellectual Capital. Vol. 6 No. 2, pp. 159-176.

Chu S. K. W., Chan K. H. \& Wu W. W.Y. (2011). Charting intellectual capital performance of the gateway to China. Journal of Intellectual Capital. Vol. 12 No. 2, pp. 249-276.

Firer S. \& Williams S. M. (2003). Intellectual capital and traditional measures of corporate performance. Journal of Intellectual Capital. Vol. 4 No. 3, pp. 348-360.

Ghozali I. (2011). Aplikasi Analisis Multivariate dengan Program IBM SPSS19, Edisi 5. Badan Penerbit Universitas Diponegoro, 2011.

Gujarati D. N. \& Porter, D. C. (2010). Dasar-dasar Ekonometrika (basics econometrics). Buku 1, Edisi 5. Penerbit Salemba Empat, 2011.

Chan H. K. (2009a). Impact of intellectual capital on organisational performance, An empirical study of companies in the Hang Seng Index (Part 1). The Learning Organization. Vol. 16 No. 1, pp. 4-21.

. (2009b). Impact of intellectual capital on organisational performance, An empirical study of companies in the Hang Seng Index (Part 2). The Learning Organization. Vol. 16 No. 1, pp. 22-39.

Kannan G. \& Aulbur W. G. (2004). Intellectual capital, Measurement effectiveness. Journal of Intellectual Capital. Vol. 5 No. 3, pp. 389-413. 
Mehralian G, Rajabzadeh A, Sadeh M. R. \& Rasekh H. R. (2012). Intellectual capital and corporate performance in Iranian pharmaceutical industry. Journal of Intellectual Capital. Vol. 13 No. 1, pp. 138-158.

Nazari J. A. \& Herremans I. M. (2007). Extended VAIC model: measuring intellectual capital components. Journal of Intellectual Capital. Vol. 8 No. 4, pp. 595-609.

OECD-Organisation For Economic Co-Operation And Development. (2006). "Creating value from intellectual assets" paper presented at Meeting of the OECD Council at Ministerial Level, Paris.

Pal K. \& Soriya S. (2012). IC performance of Indian pharmaceutical and textile industry. Journal of Intellectual Capital. Vol. 13 No. 1, pp. 120-137.

Pulic A. (2004). Intellectual capital - does it create or destroy value? Measuring Business Excellence. VOL. 8 NO. 1, pp. 62-68.

Riahi-Belkaoui A. (2003). Intellectual capital and firm performance of US multinational firms, A study of the resource-based and stakeholder views. Journal of Intellectual Capital. Vol. 4 No. 2, pp. 215-226.

(1989). Behavioral Accounting, The Research and Practical Issues. Quorum Books, New York, Westport, Connecticut, London.

Solikhah B., Rohman A. \& Meiranto W. (2010). Implikasi Intellectual Capital Terhadap Financial Performance, Growth, dan Market Value, Studi Empiris dengan Pendekatan Simplistic Specification. Simposium Nasional Akuntansi XIII Purwokerto, 2010.

Stewart T. A. (1997). Modal Intelektual, Kekayaan Baru Organisasi. Jakarta: PT Elex Media Komputindo.

Sullivan Jr. P. H. \& Sullivan Sr. P. H. (2000). Valuing intangibles companies, An intellectual capital approach. Journal of Intellectual Capital, Vol. 1 No. 4, pp. 328-340.

Ulum I., Ghozali I. \& Chariri A. (2008). Intellectual Capital dan Kinerja Keuangan Perusahaan; Suatu Analisis Dengan Pendekatan Partial Least Squares. Simposium Nasional Akuntansi XI Pontianak, 2008.

Veltri S. \& Silvestri A. (2011). Direct and indirect effects of human capital on firm value: evidence from Italian companies. Journal of Human Resource Costing \& Accounting. Vol. 15 No. 3, pp. 232-254.

Wernerfelt B. (1984). A Resource-based View of the Firm. Strategic Management Journal. Vol.5, 171-180 (1984).

Widarjo W. (2011). Pengaruh Modal Intelektual dan Pengungkapan Modal Intelektual pada Nilai Perusahaan. Simposium Nasional Akuntansi XIV Aceh, 2011.

Yuniasih N. W., Wirama D. G. \& Badera, I D. N. 2010. Eksplorasi Kinerja Pasar Perusahaan: Kajian Berdasarkan Modal Intelektual (Studi Empiris pada Perusahaan Keuangan Yang Terdaftar di Bursa Efek Indonesia). Simposium Nasional Akuntansi XIII Purwokerto, 2010.

Zéghal D \& Maaloul, A. (2010). Analysing value added as an indicator of intellectual capital and its consequences on company performance. Journal of Intellectual Capital. Vol. 11 No. 1, pp. 39-60. 
Tabel 1. Perolehan sampel penelitian (data sekunder yang diolah, 2012)

\begin{tabular}{llrr}
\hline No. & \multicolumn{1}{c}{ Kriteria } & Jumlah & Akumulasi \\
\hline 1 & Jumlah perusahaan non sektor pertambangan yang & 359 & 359 \\
& tercatat di BEI hingga tahun 2011 & 329 & 30 \\
2 & $\begin{array}{l}\text { Data tidak tersedia/tidak lengkap dan intens R\&D } \\
\text { Perusahaan dengan negatif nilai buku stockholders } \\
\text { equity, atau perusahaan dengan nilai negatif HC atau SC }\end{array}$ & 9 & 21 \\
Jumlah Sampel & 63 \\
& Jumlah observasi = jumlah sampel * tiga tahun (2009- & \\
$2011)$
\end{tabular}

Tabel 2. Deskriptif statistik variabel dependen, independen, kontrol (data sekunder yang diolah dengan SPSS 17, 2012)

\begin{tabular}{|c|c|c|c|c|c|c|c|c|c|c|c|}
\hline \multirow[b]{2}{*}{ Variabel } & \multirow{2}{*}{$\frac{\mathrm{N}}{\text { Stat. }}$} & \multirow{2}{*}{$\frac{\text { Min }}{\text { Stat. }}$} & \multirow{2}{*}{$\frac{\text { Max }}{\text { Stat. }}$} & \multirow{2}{*}{$\frac{\text { Sum }}{\text { Stat. }}$} & \multicolumn{2}{|c|}{ Mean } & \multirow{2}{*}{$\begin{array}{r}\text { SD } \\
\text { Stat. }\end{array}$} & \multicolumn{2}{|c|}{ Skewness } & \multicolumn{2}{|c|}{ Kurtosis } \\
\hline & & & & & Stat. & $\mathrm{SE}$ & & Stat. & $\mathrm{SE}$ & Stat. & $\mathrm{SE}$ \\
\hline $\mathrm{M} / \mathrm{B}$ & 63 & .3371 & 38.9694 & 251.3803 & 3.990163 & .8144973 & 6.4648721 & 4.231 & .302 & 18.856 & .595 \\
\hline ROA & 63 & .001 & .563 & 9.657 & .15328 & .016927 & .134358 & 1.288 & .302 & 1.370 & .595 \\
\hline VAIC & 63 & 1.3597 & 7.7570 & 220.9568 & 3.507251 & .2176469 & 1.7275184 & .991 & .302 & -.141 & .595 \\
\hline $\mathrm{HCE}$ & 63 & 1.0406 & 6.5541 & 162.4471 & 2.578525 & .1821424 & 1.4457106 & 1.179 & .302 & .344 & .595 \\
\hline SCE & 63 & .0390 & .8474 & 31.5728 & .501156 & .0286927 & .2277410 & -.340 & .302 & -.788 & .595 \\
\hline CEE & 63 & .1270 & 1.3823 & 26.9374 & .427578 & .0321918 & .2555141 & 1.811 & .302 & 3.553 & .595 \\
\hline ICE & 63 & 1.0795 & 7.4015 & 194.0198 & 3.079679 & .2079265 & 1.6503656 & 1.001 & .302 & .034 & .595 \\
\hline DEBT & 63 & .109 & .915 & 28.265 & .44864 & .032463 & .257669 & .619 & .302 & -.936 & .595 \\
\hline SIZE & 63 & 10.9829 & 19.0652 & 965.7927 & 15.330043 & .3135300 & 2.4885670 & -.142 & .302 & -1.318 & .595 \\
\hline $\begin{array}{l}\text { Valid N } \\
\text { (listwise) }\end{array}$ & 63 & & & & & & & & & & \\
\hline
\end{tabular}

Tabel 3: Model empiris sebelum dan sesudah uji asumsi klasik

Model Model Awal Model Setelah Transformasi

(1) (2)

(3)

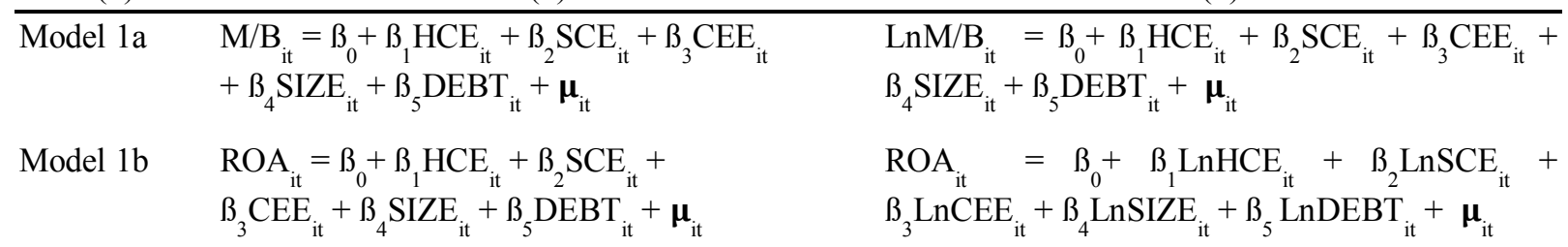

Model 2a Model 2a menggunakan data pada Model 1a yang telah ditransformasi, dimana penginteraksian yang diukur dengan nilai absolute perbedaan antara nilai standardized HCE dan SCE.

Model 2b Model 2b menggunakan data pada Model $1 \mathrm{~b}$ yang telah ditransformasi, dimana penginteraksian yang diukur dengan nilai absolute perbedaan antara nilai standardized HCE dan SCE. 


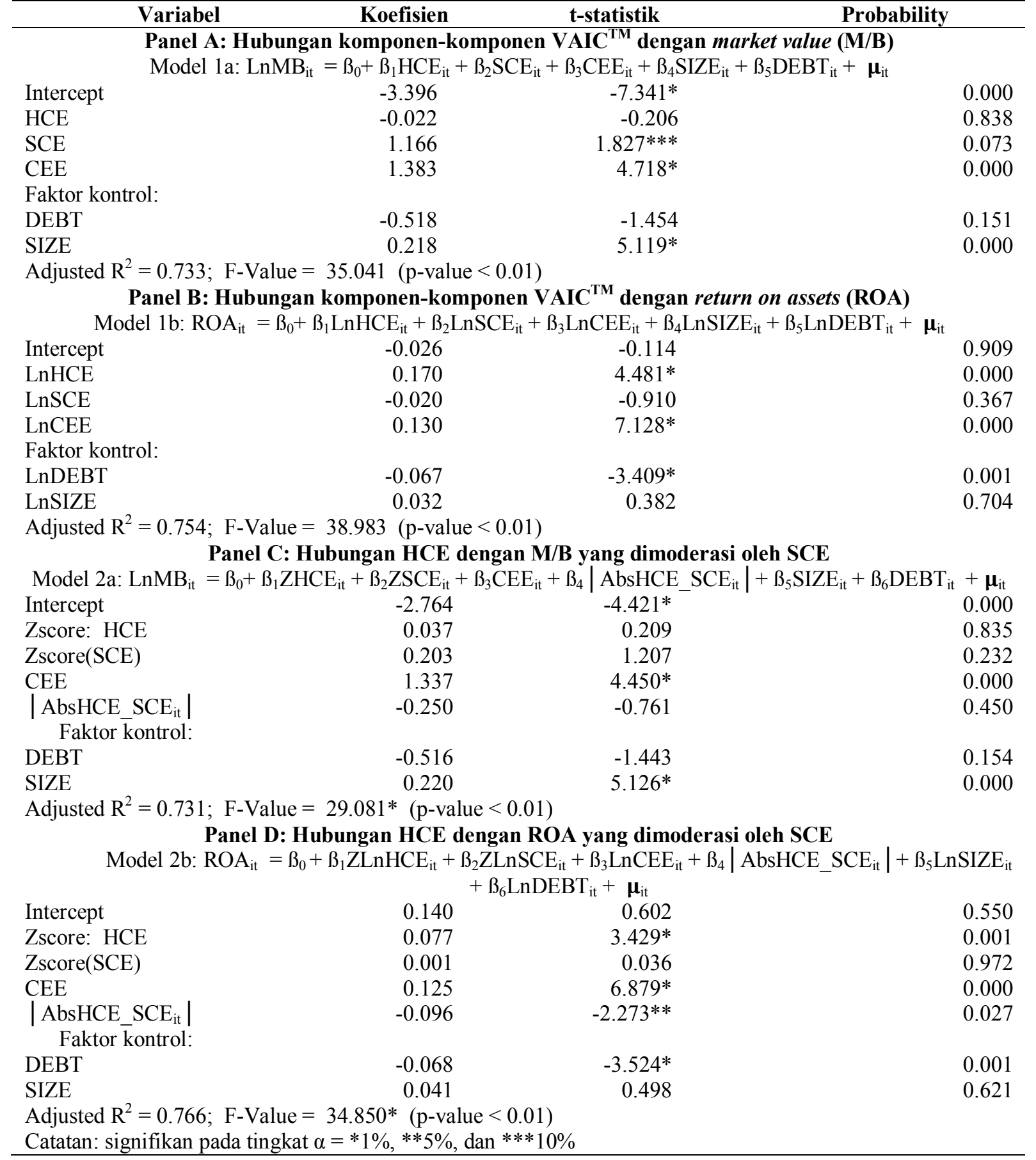

